\title{
Dental Care Clothing: An Investigation the Presence of Bacteria Contamination by Public Health Professionals in Southern Brazil
}

\author{
Reis $\mathrm{PF}^{1 *}$, Pagliari BG ${ }^{1}$, Reis $\mathrm{CMA}^{2}$, Moro ARP ${ }^{2}$, Santos $\mathrm{JB}^{3}$, Freire $\mathrm{ACGF}^{4}$ and Vilagra $\mathrm{JM}^{5}$ \\ ${ }^{1}$ Ergonomics Laboratory, Centro Universitário Dinâmica Cataratas - UDC, Rua Castelo Branco, 349, Foz do lguaçu, Parana 85852010, Brazil \\ ${ }^{2}$ Biomechanics and Ergonomics Laboratory, Federal University of Santa Catarina - UFSC - Florianópolis, Brazil \\ ${ }^{3}$ Study of Human Posture, São Paulo, Brazil \\ ${ }^{4}$ Department of Dentistry Araçatuba - FOA-UNESP - São Paulo, Brazil \\ ${ }^{5}$ Department of Physiotherapy - UNIOESTE - Cascavel, Brazil
}

\begin{abstract}
This study aimed to identify microorganisms present in contaminated dental lab coats and determine the risks of microbial contamination to professionals and patients. The study included 10 dentists of the city of Foz do Iguaçu, state of Paraná, Brazil, who signed an informed consent form according to the ethics committee on human research. Microbiological samples were collected from coats using the rolling swab technique, passing a single swab moist in BHI medium in the collar, cuffs and pockets. A questionnaire with open and closed questions was used. Statistical data were tabulated and described in a descriptive analysis through the bioestatic software 5.0. Regarding coat sanitization, $80 \%$ of respondents adopted this procedure every five days of use. Diagnosed microorganisms were: Klebsiella sp., Staphylococcus saprophyticus, Enterobacter sp., Staphylococcus epidermidis, Staphylococcus aureus. Staphylococcus aureus (50\%) and Staphylococcus epidermidis $(40 \%)$ were the most predominant bacteria found, especially in coats analyzed at the end of the workday, which may cause diseases such as: folliculitis, furuncle, endocarditis, meningitis, osteomyelitis, arthritis, urinary tract infections and others. Based on results, it was found that the lab coats of dentists are contaminated by microorganisms considered of clinical importance, contributing to a possible spread of diseasecausing microorganisms among dentists and patients.
\end{abstract}

Keywords: Protective clothing; Contamination; Bacteria; Dentistry; Staphylococcus saprophyticus

\section{Introduction}

Diseases in the working environment caused by biological agents are represented by microscopic organisms, invisible to the naked eye, such as bacteria, viruses, fungi, worms and ectoparasites that, provided with pathogenic activity, may affect the human body by modifying the vital ability of organs and causing partial or total incapacity to perform labor activities [1].

In the health field, professionals should adopt biosafety measures to prevent, minimize and, as far as possible, eliminate the inherent risks to occupational activities they perform in the community in general. This is justified because they are more exposed to contamination and / or disease transmission through direct or indirect contact with body fluids [2-4]. Specifically in the area of dentistry, professionals are daily exposed to pathogenic microorganisms, present in the surrounding environment and originated from the mouths of patients [5].

In terms of prevention, biosafety acts with procedures, actions, techniques and equipment to reduce the risks of infections such as common cold, pneumonia, tuberculosis, AIDS, hepatitis B, hepatitis $\mathrm{C}$, among other diseases. Thus, in addition to professionals, patients should also be clarified about the risks of the exposure to these microorganisms [6].

Biosafety standards comprise all measures that tend to prevent the occurrence of physical risks, which are those caused by various forms of energy, such as heat, cold, noise, among others, ergonomic risks, which are mainly caused by poor posture or inadequate furniture, chemical hazards, which are caused by substances, compounds or materials that can penetrate the body, and biological hazards, which are caused by living organisms, such as parasites, bacteria, fungi, and protozoa.

One of the biosafety measures that interfere with the infection chain is the use of personal protective equipment, called PPE. These include caps, gloves, footwear, goggles, masks, lab coats (apron), among other equipment, and their use depends on the activity being performed and the risks of exposure by health professionals $[7,8]$.

However, personal protective equipment, when improperly used or with poor conservation, maintenance, storage, transportation, and particularly with respect to hygiene, may end up by becoming a source of contamination, as they lose their original protective conditions $[9,10]$.

Coat, a device widely used by health professionals, when contaminated, can be a source of concern, because instead of being a protective equipment, becomes a source and vehicle of transmission of various sensitive and resistant microorganisms [11].

It is not difficult to see health professionals attending public places such as supermarkets, restaurants, pharmacies, coffee shops, and other locations outside their work environment using the coat or even carrying it with them. It is believed that this behavior is due to cultural and social issues, professional status, symbolism, distinction between professional and patient. However, Regulatory Standard 32 allows health professionals to leave their workplace with personal protective equipment and clothing used in their work routines.

*Corresonding author: Reis PF, Ergonomics Laboratory, Centro Universitário Dinâmica Cataratas - UDC, Rua Castelo Branco, 349, Foz do Iguaçu, Parana 85852010, Brazil, Tel: 55-45-99241969/ 55-45-35410158; Fax: 55-45-35201727; E-mail: ergoreis@hotmail.com, isioterapeutadotrabalho@hotmail.com

Received October 31, 2014; Accepted November 27, 2014; Published January 07, 2015

Citation: Reis PF, Pagliari BG, Reis CMA, Moro ARP, Santos JB, et al. (2015) Dental Care Clothing: An Investigation the Presence of Bacteria Contamination by Public Health Professionals in Southern Brazil. J Food Process Technol 6: 407. doi:10.4172/2157-7110.1000407

Copyright: (c) 2015 Reis PF, et al. This is an open-access article distributed under the terms of the Creative Commons Attribution License, which permits unrestricted use, distribution, and reproduction in any medium, provided the original author and source are credited. 
The interest in analyzing the lab coat of dentists arose because dentistry is characterized as a profession where professionals are in contact with various biological agents due to the close proximity to the patient during treatment, which ends up by exposing professional to blood, saliva, mucous, and other body fluids, which makes professionals, staff and patients susceptible to contamination.

In this sense, the aim of this study was to identify the presence of microorganisms on the surface of coats used by dentists working in various municipal health systems in the city of Foz do Iguaçu. In addition, a questionnaire with information about the risks of contamination by microorganisms and the perception of professionals about strategies to improve the design of coats was applied in order to improve hygiene and thus avoid possible contamination.

\section{Method}

\section{Study participants}

The study was conducted with the participation of dentists of various dental clinics belonging to five (5) health units of the city of Foz do Iguaçu - Paraná, Brazil.

The random sample consisted of ten (10) dentists who agreed to participate in the study, six (6) males and four (4) females, aged 25-63 years.

Dentistry assistants were not included in the study.

\section{Data collection}

Dentists were verbally and individually asked to participate in the present study. After acceptance, they signed the Informed Consent Form, following the ethical principles of research, which included goals, purpose and social importance of the research, in addition to the confidentiality aspects and free participation according to Resolution of the National Health Council (CNS 196/96).

The collection of microbiological samples from dental lab coats was performed by the technique of rolling a swab, which consists in passing the swab on the target site. For this, sterile swabs with wooden rod were used, which were moistened in BHI medium for antibiogram purposes (Figure 1)

As a reference to the sampling points, procedures followed similar studies, which pointed out pockets and the abdomen region as the most critical points due to the possible direct contact of these places with the patient or by contact with environmental surfaces, stethoscopes, medical equipment and instruments, among others [12].

Thus, the points of dental lab coats from which microbial samples were collected were: collar (Figure 2), sleeve (Figure 3) and pocket (Figure 4). The choice of these areas was due to the frequency of touches of dentists' hands and the direct contact with patients during the performance of routine dental procedures. The sample collection procedure was always performed at the beginning and end of the workday of each participant.

Before sample collection, it was mentioned about the importance of avoiding any contact between researchers and participants during the procedure to avoid interference in results. Likewise, researchers made careful hand hygiene and used disposable gloves for each collection or use.

In the present study, a single swab was used to pass at different points of the coats of each participant. After this procedure, the swab was transferred to a test tube in BHI medium and stored on a shelf inside a small styrofoam box to be forwarded to the laboratory for analysis.

Collections were made according to the availability of professionals during office hours at different dental clinics in the city on the last day of the workweek.

To complement data collection, a questionnaire consisting of open and closed questions addressing information on organizational routines and procedures adopted in dental clinics was applied. This questionnaire was filled by dentists only after the workday after performing the last procedure of collecting microbiological samples from dental lab coats. Microbial analyses were performed by a clinical analysis laboratory located in the city of Foz do Iguaçu - PR. It is a traditional laboratory in the city, whose professionals are of great technical capacity and responsibility demonstrated mainly by the correct form of collection, storage and transportation of the material.

\section{Results and Discussion}

It was verified that the workday of the group of professionals who participated in the study was 6 hours, or 30 hours weekly. In the morning shift, they started work at 7:00 a.m. and ended at 01:00 p.m. and in the afternoon shift, they started work at 01:00 p.m. and ended at 07:00 p.m.

Table 1 shows the number of dental treatments performed by every dentist during their workday at municipal clinics of the city on the day of data collection. It was identified that the frequency of dental treatments ranged from 4 to 12 patients per day. However, the average number of daily treatments of most professionals was 8 patients.

Table 2 shows the time interval (in hours) in which each dentist reported to make coat sanitization. The results showed that most professionals do coat sanitization (washing) once a week, except for

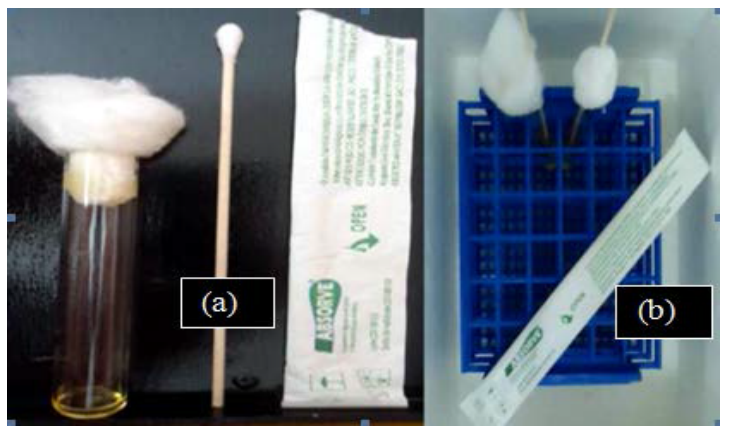

Figure 1: Test tube with $\mathrm{BHI}$ and sterile swab with wooden rod (a) and Styrofoam box with test tubes (b) used in data collection.

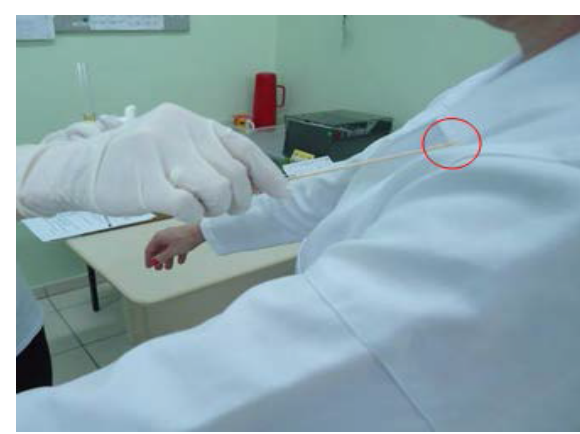

Figure 2: Collection of biological sample from coat collar 


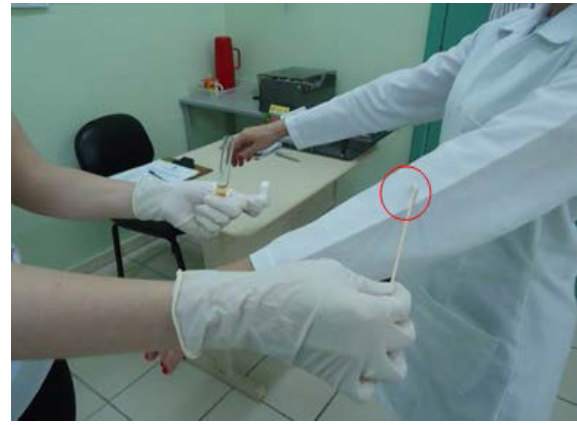

Figure 3: Collection of biological sample from coat sleeve.

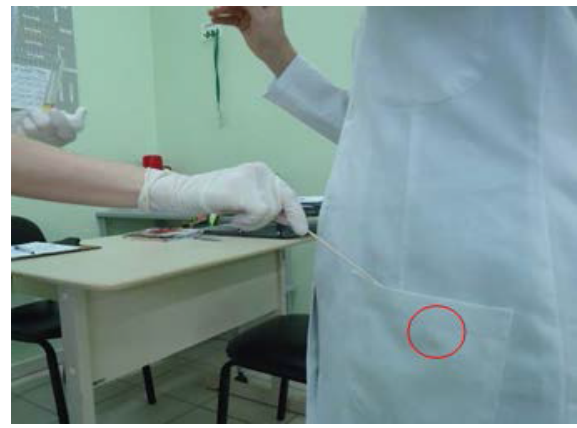

Figure 4: Collection of biological sample from coat pocket.

\begin{tabular}{|c|c|c|c|}
\hline Dentist & Sex & Treatments & Percentage \\
\hline 1 & M & 7 & $10 \%$ \\
\hline 2 & F & 4 & $5 \%$ \\
\hline 3 & M & 6 & $7 \%$ \\
\hline 4 & M & 8 & $11 \%$ \\
\hline 5 & M & 12 & $15 \%$ \\
\hline 6 & M & 10 & $13 \%$ \\
\hline 7 & M & 8 & $11 \%$ \\
\hline 8 & F & 7 & $10 \%$ \\
\hline 9 & F & 6 & $7 \%$ \\
\hline 10 & F & 8 & $11 \%$ \\
\hline Total & & 76 & $100 \%$ \\
\hline
\end{tabular}

Table 1: Number of patients treated on the day of data collection at each dental clinic.

\begin{tabular}{|c|c|c|}
\hline Dentist & Coat sanitization /day & Time in hors \\
\hline 1 & 7 & $168 \mathrm{hs}$ \\
\hline 2 & 3 & $72 \mathrm{hs}$ \\
\hline 3 & 7 & $168 \mathrm{hs}$ \\
\hline 4 & 7 & $168 \mathrm{hs}$ \\
\hline 5 & 7 & $168 \mathrm{hs}$ \\
\hline 6 & 7 & $168 \mathrm{hs}$ \\
\hline 7 & 7 & $168 \mathrm{hs}$ \\
\hline 8 & 7 & $168 \mathrm{hs}$ \\
\hline 10 & 3 & $72 \mathrm{hs}$ \\
\hline
\end{tabular}

Table 2: Time interval of coat sanitization according to dentists included in the study

two cases in which they do this procedure every three days on average.

Coats submitted to lower frequency of exchange and washing tend to show higher incidence of contamination. Likewise, longer use has a direct relationship with increased contamination. Thus, aspects such as frequency of exchange, use outside the office, place of washing, among other factors, may contribute to the increased risk of contamination and transfer of microorganisms from different environments and patients.

Data regarding the presence of bacteria in coats are shown in Table 3. According to results, most dental coats used by professionals showed presence of bacteria, mainly of the genus Staphylococcus, followed by Klebsiella and Enterobacter. Five cases were positive for two types of bacteria, 4 for only one type and 1 showed no contamination.

Staphylococci represent the major pathogens of the group of Enterobacter bacteria, which are responsible for causing several infections to humans. They are facultative anaerobic gram-negative cocci mainly found in the skin and mucosa and have three types: Staphylococcus aureus, Staphylococcus epidermidis and Staphylococcus haemolyticus [13]. Health professionals are the most vulnerable to colonization, and the main form of transmission is through temporarily colonized hands. Importantly, treatment of infections caused by Staphylococcus aureus has become increasingly difficult mainly due to high resistance of microorganisms to various drugs, thus, susceptibility test should be performed before drug prescription [14].

Staphylococcus aureus is part of the normal human microbiota and can be found in the nasal passages, throat, gastrointestinal tract and skin. It is considered one of the most important pathogenic bacteria, as it acts as agent in a series of infections $[15,16]$. The hallmark of staphylococcal infection is the formation of abscess that follows the inflammatory process. Abscess is a cavity filled with purulent exudate coated with a layer of fibrin and phagocytic cells, whose function is to avoid infection progress. Staphylococcus aureus occurs through the contact of people through hands or aerosol, airways or cloth contaminated by peeling skin and is considered the most common agent of clinical significance in human infections, such as furuncles, folliculitis, scalded skin syndrome, meningitis, pneumonia.

Staphylococcus epidermidis is part of the normal human microflora and can be found in the skin and mucous membranes, being considered dominant due to its capacity to produce substances that inhibit the growth of other gram-positive bacteria that could cause competition and also due to its ability to adhere to plastic surfaces, forming a biofilm. Thus, the main diseases caused by $\mathrm{S}$. epidermidis are endocarditis, meningitis, osteomyelitis, arthritis, urinary tract infections, among others.

Treatment of infections caused by Staphylococcus epidermidis has become increasingly difficult mainly due to the high resistance to several drugs, which is similar to that of $\mathrm{S}$. aureus, thus, susceptibility test should be performed before drug prescription.

Staphylococcus saprofiticus is part of the normal human

\begin{tabular}{|l|l|}
\hline Dentist & Bacteria \\
\hline 1 & Klebsiella sp., Staphylococcus saprofiticius \\
\hline 2 & Enterobacter sp., Staphylococcus epidermidis \\
\hline 3 & Klebsiella sp., Staphylococcus aureus \\
\hline 4 & No growth was observed after 24 h of incubation \\
\hline 5 & Staphylococcus epidermidis \\
\hline 6 & Staphylococcus aureus \\
\hline 7 & Staphylococcus epidermidis \\
\hline 8 & Staphylococcus epidermidis \\
\hline 9 & Staphylococcus aureus \\
\hline 10 & Staphylococcus aureus, Staphylococcus epidermidis \\
\hline
\end{tabular}

Table 3: Type and amount of bacteria diagnosed in dental lab coats 
microbiota and can be found in the skin and in the periurethral region of men and women. After Escherichia coli, S. saprofiticus is the most common agent causing urinary tract infection in women, especially in those aged 20-40 years, and in men, especially after the age of 50 .

Klebsiella pneumoniae is considered the most isolated species, found in the stool of $30 \%$ of healthy people, and less frequently, in the nasopharyngeal region, which is considered one of the major causes for the occurrence of pneumonia, bacteremia and infections in other organs. The genus Klebsiella has greater ability to disperse from one person to another mainly through contaminated hands.

Bacteria of the family Enterobacteriaceae are considered the most important, including gram-negative bacteria such as Klebsiella $s p$., Enterobacter sp., Serratia sp, Proteus sp., Escherichia coli, Citrobacter sp., Salmonella sp., Edwarsiella sp., Cedecea sp., Leminorella sp., and many other species [17]. Enterobacteriaceae can cause intestinal and extra-intestinal infections. Those of genera Klebsiella, Enterobacter, and Serratia are undemanding bacteria that inhabit the gastrointestinal tract and the skin of humans, being normally transported through contaminated hands. These bacteria can infect and reproduce in wet and little nutritional environments such as dental clinics.

Unlike the others, the lab coat of dentist 04, even with 168 hours without sanitation, showed no presence of bacteria before or even after 6 hours of work with patients. This fact can be attributed to good professional biosafety, socioeconomic level of patients and the hygiene status of patients, which were variables not controlled in this study.

Table 4 shows the number of cases of contamination of coats identified by the results of laboratory microbiological analyses.

Table 4 shows with greater precision that Staphylococcus epidermidis and Staphylococcus aureus bacteria were the most prevalent in coats analyzed at the beginning and end of the workday, according to studies that found that Staphylococcus was the most prevalent genus in both areas of coats analyzed. This author warns that loose hair releases large amounts of fragments that can carry bacteria, mostly pathogenic, among them, Staphylococcus aureus.

As a result of this contamination, diseases known as endocarditis, meningitis, osteomyelitis, arthritis, urinary tract infections, and others can be mentioned, all related to the presence of Staphylococcus epidermidis found in most coats.

As shown in Table 5 there was no statistical significance between number of patients attended and the amount of bacteria found $(\mathrm{P}<0.05)$. This does not rule out the presence of a greater number of these microorganisms, given that sampling was performed in only one day.

However, there is statistical significance between lab coat sanitation and bacteria found $(\mathrm{P} \leq 0.05)$, which reinforces the presence of bacteria in lab coats of dentists evaluated. According to several studies on the subject focused on the presence of bacteria in dental offices, warning health professionals and the general population about the importance of good biosafety for health professionals especially in the dentistry area is of utmost importance.

It has been observed that professionals often neglect the presence of diseases caused by biological agents that are represented by microscopic organisms, invisible to the naked eye, such as bacteria, viruses, fungi, worms, ectoparasites, and that these pathogenic agents can contaminate their work environment.
It is of essential importance to meet standards for the prevention of risks, as biological agents expose humans and the environment to the risk of diseases, and in the dentistry area, due to the close proximity to the patient during professional practice, the dentist runs several risks of biological contamination. The same authors warns that contamination may occur through contaminated instruments or objects from person to person, i.e. from patient to dentist or by means of the so-called contamination vector through contaminated or inadequately sterilized surgical instrument, transferring contamination from patient to patient or from patient to professional.

Simple actions, such as washing hands before and after every patient considerably decrease the occurrence of such contamination. Skin and mucous membranes are considered the first defense of the body against the external environment.

Dental lab coat or individual protection equipment are mechanisms designed to protect the worker's health, for a biosafe work environment and to provide conditions that favor comfort and freedom of movement. Some authors report that the usual personal protective equipment in the field of dentistry are cap, mask, gloves for medical and surgical care, lab coat, goggles and footwear, and these personal protective equipment must be used by healthcare professionals with responsibility.

Cap is used to avoid hair to be a means of contamination due to aerosols, secretions and chemicals and also to prevent hair from falling on equipment or patients, and the cap should cover the entire hair and ears in situations that require precautions with blood and other body fluids. In this sense, loose hair releases large amount of debris that can carry bacteria, mostly pathogenic, among them, Staphylococcus aureus.

Mask serves to prevent contamination of face with blood, saliva, secretions and other body fluids and also not to contaminate the environment, equipment or patient, being necessary to cover nose and mouth. These can be disposable, but should be resistant to contact with fluids and should be replaced when they are wet, and in case of contact with patients with more severe contamination, the use of masks with respirators is necessary. Hands must be washed thoroughly before

\begin{tabular}{|l|c|c|}
\hline Bacteria & Beginning & End \\
\hline Klebsiella sp. & $\mathrm{XX}$ & $\mathrm{XX}$ \\
\hline Staphylococcus saprofiticius & $\mathrm{X}$ & $\mathrm{X}$ \\
\hline Enterobacter sp. & $\mathrm{X}$ & $\mathrm{X}$ \\
\hline Staphylococcus epidermidis & $\mathrm{XXX}$ & $\mathrm{XXXX}$ \\
\hline Staphylococcus aureus & $\mathbf{X X}$ & $\mathbf{X X X X X}$ \\
\hline
\end{tabular}

Table 4: Bacteria present at the beginning and end of the workday of dentists according to cases of occurrence.

\begin{tabular}{|l|c|c|}
\hline Correlation & $\begin{array}{c}\text { Patients attended } \\
\mathbf{X} \\
\text { Bacteria found }\end{array}$ & $\begin{array}{c}\text { Lab coat sanitization } \\
\mathbf{X} \\
\text { Bacteria found }\end{array}$ \\
\hline $\mathrm{n}$ (pares) & 10 & 10 \\
\hline $\mathbf{r}$ (Pearson) & $-\mathbf{0 . 5 0 4 0}$ & $\mathbf{- 0 . 1 5 6 2}$ \\
\hline IC $95 \%$ & -0.86 a 0.18 & -0.72 a 0.53 \\
\hline IC $99 \%$ & -0.91 a 0.40 & -0.81 a 0.67 \\
\hline R2 & 0.2540 & 0.0244 \\
\hline$t$ & -1.6505 & -0.4472 \\
\hline GL & 8 & 8 \\
\hline (p) & 0.1374 & 0.6666 \\
\hline Poder $\mathbf{0 . 0 5}$ & $\mathbf{0 . 7 7 4 6}$ & $\mathbf{0 . 0 2 5 7}$ \\
\hline Poder 0.01 & 11.9484 & 0.2822 \\
\hline
\end{tabular}

Table 5: Correlation between patients attended, lab coat sanitation and bacteria found. 
putting on the mask, which should be fitted to nose and mouth, under any circumstances, they should be touched, hung around the neck and / or ears, or kept in coat pocket after being used to avoid possible contamination.

Gloves are used to avoid contamination of hands with blood, saliva, mucous, and other body fluids or with contaminated surface, and should cover the wrists. Standards recommend that these do not need to be sterile, since hands are sanitized before and after use of gloves, but should be replaced by new ones every patient treated. Only in surgical procedures, the use of sterile gloves is necessary [18-21].

The function of the dental coat is to prevent contamination of the front part of clothes and should have long sleeves, covering wrists and closure to the neck area in order to keep this area unexposed $[22,23]$.

As for gloves, the dental lab coat does not need to be sterile during routine patient care. However, it must be sanitized; it should be long, with long sleeves and made from durable fabric to avoid possible contact with body fluids released during work, which may possibly come to contaminate clothes and especially the professional. Sterile and disposable coats are needed only during surgical procedures [2429].

\section{Conclusion}

Based on results, it was found that the lab coats of dentists were contaminated by microorganisms considered of clinical importance, contributing to a possible spread of disease-causing microorganisms among dentists, staff and patients.

Further studies should be carried out in the area of materials technology aimed at the development of waterproof, disposable and / or durable and inexpensive fabrics, so that in each procedure with several patients during the workday, dentists can develop their activities with more comfort, health and safety.

In order to prevent risks of contamination, basic prevention practices should be adopted by health professionals, from the simplest to the most complex, among which washing hands with soap and water, vaccines should be updated, and especially use of personal protective equipment.

Finally, it is important to emphasize that prevention is the best way for a healthy environment to ensure safety for both health professionals, patients and their families, given that bacterial infection may compromise all people in society, thus, reinforcing the importance of maintaining and promoting public health programs aimed at the prevention of such risks.

\section{References}

1. Marano PV (2007) Doenças Ocupacionais. São Paulo.

2. Almeida CB, Pagliuca LMF, Leite A (2005) Acidentes de trabalho envolvendo os olhos: avaliação de riscos ocupacionais com trabalhadores de enfermagem. Rev Latino-Americana de Enferm 13: 708-716.

3. Ribeiro PHV (2005) Acidentes com material biológico potencialmente contaminado em alunos de um curso de odontologia do interior do estado do Paraná. Dissertação (Mestrado)-Universidade de São Paulo, Escola de Enfermagem de Ribeirão Preto, Ribeirão Preto.

4. Hirata MH, Hirata RDC, Filho JM (2012) Manual de Biossegurança. Manole.

5. Balsamo AC, Felli V (2006) Estudo sobre os acidentes de trabalho com exposição aos líquidos corporais humanos em trabalhadores da saúde de um hospital universitário. Rev Latino-Americana Enferm 14:346-353.

6. Bugarin JJG, GARRAFA V (2007) Bioética e biossegurança: uso de biomateriais na prática odontológica. Ver Saude Publ 41: 223-228.
7. Santos FS (2010) Manual de Biossegurança do Curso de Odontologia do Centro Universitário da Fundação Educacional de Barretos.

8. BrasiL (2010) NR 6 - Equipamento de Proteção Individual - EPI. Portaria GM $n^{\circ} 3.214$, de 08 de junho de Acesso em.

9. Oliveira ACO, Silva MDM (2013) Caracterização epidemiológica dos microrganismos presentes em jalecos dos profissionais de saúde de um hospital geral. Rev Eletr Enf 15: 80-87.

10. Brasil (2011) NR 32 - Segurança e Saúde no Trabalho em Serviços de Saúde. Disponivel em.

11. Carvalho CMRS (2009) Aspectos de biossegurança relacionados ao uso do jaleco pelos profissionais de saúde: uma revisão da literatura. Texto contextenferm 18: 355-360.

12. Garcia LP, Blank VLG (2006) Prevalência de exposições ocupacionais de cirurgiões-dentistas e auxiliares de consultório dentário a material biológico. Cad. Saude Publ 22: 97-108.

13. Hinrichsen SL (2013) Biossegurança e controle de infecções - Risco sanitário hospitalar. ( $2^{\text {nd }}$ edition). Rio de Janeiro: Guanabara Koogan.

14. Trabulsi LR, Alterthum F (2007) Microbiologia. São Paulo: Atheneu.

15. Camargo RA, Schimim SC, Alves FBT, Chibinski ACR (2013) Avaliação microbiológica da efetividade de uma escova antibacteriana: um estudo in vivo. Rev odontol UNESP 42: 54-58.

16. Santos ALS (2007) Staphylococcus aureus: Visitando uma Cepa de Importância Hospitalar. J Bras Patol Med Lab 43: 413-423.

17. Prado M (2007) Staphylococcus aureus e Staphylococcus aureus meticilina resistente (MRSA) em profissionais de saúde e as interfaces com as infecções nosocomiais. Rev Eletr Enf 9: 880-879.

18. Andrade D, Angerami E, Padovani C (2000) Condição microbiológica dos leitos hospitalares antes e depois de sua limpeza. Rev Saude Publ 34: 163-169.

19. Brasil (2010) NR 9 - Programa de Prevenção de Riscos Ambientais. Portaria $\mathrm{GM}$ n. ${ }^{\circ} 3.214$, de 08 de junho de 2010b. Disponível em.

20. Brasil (1987) Diretrizes e Normas Regulamentadoras de Pesquisas Envolvendo Seres Humanos. Resolução 196/96 de 14 de janeiro de 1987. Disponível em.

21. Garcia LP, Blank VLG, Blank, N (2007) Aderência a medidas de proteção individual contra a hepatite $B$ entre cirurgiões-dentistas e auxiliares de consultório dentário. Rev bras epidemiol 10: 525-535.

22. Chaves MC, Miranda AS (2008) Discursos de cirurgiões-dentistas do Programa Saúde da Família: crise e mudança de habitus na Saúde Pública. Interface (Botucatu) 12: 153-167.

23. Silva CRG, Jorge AOC (2002) Avaliação de desinfetantes de superfície utilizados em Odontologia. Pesqui Odontol Bras 16: 107-114.

24. Azeredo F (2011) Microbiological analysis of orthodontic pliers. Dental Press J Orthod 16: 103-112.

25. Scannavino FLF (2006) Sucção de alta potência no controle das partículas emitidas pelo sistema de abrasão a ar em consultório odontológico. Rev bras saúde ocup 31: 49-56.

26. Santos CC, Peçanha MP (2009) Presença de bactérias Staphylococcus aureus e Staphylococcus epidermidis aderidos às mascaras faciais e luvas descartáveis usadas por dentistas e auxiliares de um posto de saúde público. Revista Eletrônica de Biologia 2: 40-53.

27. Garbin AJl, Garbin CAS, Arcieri RM, Ferreira NF (2005) Biosecurity in public and private office. J Appl Oral 13: 163-166.

28. Velano HE, Nascimento LC, Barros LM (2001) Avaliação in vitro da atividade antibacteriana da água ozonizada frente ao Staphylococcus aureus. Pesqui Odontol Bras 15: 18-22.

29. Dutra SR, Santos VR, de Menezes LFS, Drummond AF, Vilaca EL, et al. (2008) Esterilização em Ortodontia: eficácia do esterilizador com esferas de vidro. Rev Dent Press Ortodon Ortop Facial 13: 60-66 